\title{
Mapping and Monitoring the Sea Surface Temperature in Weda Bay Using Terra and Aqua- Modis Satellites
}

Salam Tarigan* and Sam Wouthuyzen

De Research Center for Oceanography, Indonesian Institute of Sciences, Jakarta, Indonesia

*Corresponding author: Salam Tarigan, De Research Center for Oceanography, Indonesian Institute of Sciences, Jakarta, Indonesia, Tel: +6221 64713850; E-mail: Saltargir@yahoo.com

Rec date: October 25, 2017; Acc date: November 13, 2017; Pub date: November 15, 2017

Copyright: (C) 2017 Tarigan S, et al. This is an open-access article distributed under the terms of the Creative Commons Attribution License, which permits unrestricted use, distribution, and reproduction in any medium, provided the original author and source are credited.

\begin{abstract}
Temperature is one of the principal controls on all physical, chemical and biological processes in the environment. Therefore, temperature data play an important role in earth resources management activities, including managing the effects of climate change. In this study, the sea surface temperatures (SSTs) of Weda Bay, Halmahera Island, Indonesia were mapped and monitored, from January to November 2007, using thermal infrared (TIR) band 30 and 31 of Terra- and Aqua MODIS satellites. The empirical prediction SST model developed, using TIR band and in-situ measurement SST, showed that the model was sufficient to predict and to map the SST within the bias ranges of \pm $0.5^{\circ} \mathrm{C}$. Daily SST, averaged 10 days SST, and monthly SST maps were made using 109 available Terra- and AquaMODIS images. The ranges of daily and 10 -day average SSTs in Weda Bay were narrow, about $2^{\circ} \mathrm{C}\left(28-30^{\circ} \mathrm{C}\right)$ throughout the year, while the range for monthly SSTs was only $1^{\circ} \mathrm{C}\left(28.75-29.75^{\circ} \mathrm{C}\right)$. Accordingly, no indication of upwelling phenomena occurred in this bay during the observation (2007), but it is possible that upwelling could have happened in the past or may in the future. Long-term monitoring from space should continue in order to get a clearer understanding of the water characteristics in Weda Bay, not only using TIR, but also using ocean color bands of MODIS
\end{abstract}

Keywords: Mapping; Monitoring SST; TIR bands; Terra- AquaMODIS; Weda bay

\section{Introduction}

Temperature is one of the principal controls on all physical, chemical and biological processes in the environment. Consequently, temperature data play an important role in a wide range of earth resources management activities [1]. For over 30 years far-infrared, or Thermal Infra-Red (TIR), images of the earth's surface have been gathered by optical-mechanical scanner systems. First these were from airborne, and later from earth-orbiting, satellite platforms [2]. These images give us an opportunity to measure the radiant temperature of the earth's surface, including the sea, from a distance, by sensing in the wave-length range of 3-14 $\mu \mathrm{m}$ [1]. High-quality sea surface temperature (SST) data have been archived since the late 19th century and this makes SST one of the more robust indicators for understanding the earth's climate or for studying climate change.

Numerous investigations of the sea surface temperature have been carried out, firstly using TIR data from the "Advance Very HighResolution Radiometer (AVHRR) sensor on the board of Tiros-n/ NOAA series satellites, and following that, by sensors on board various other satellites. Most the SST estimation using those TIR sensors have been done by employing a well-established model called the "SplitWindow Model", except for those satellites that have only one band of TIR (Nimbus-7, Landsat-4, -5 and-7). This model has been used world-wide and published in many journal related to the field of remote sensing.

The earth surface energy sensed or measured in TIR region is the emitted energy of a target, not reflected energy such as invisible (0.4-0.7 $\mu \mathrm{m})$ nor reflective infrared (near and mid infrared; 0.7-2.4 $\mu \mathrm{m})$ regions. Thus, because it does not depend on reflected sunlight, thermal data (SST) can even be collected at night [3]. When the infrared radiation emitted from the ocean is discussed, wavelengths in the 3.5-4.0 $\mu \mathrm{m}$ and $10-13 \mu \mathrm{m}$ range are customarily considered. The reasons are: i). Radiant power peaks in the range of SST from 9.3-10.7 $\mu \mathrm{m}$, while ii). The atmospheric absorption minima are in the 3.5, 9.0 and $11.0 \mu \mathrm{m}$ range. Thus, as a practical matter, 3-15 $\mu \mathrm{m}$ represents a wavelength region where sufficient radiant power is available for suitable detector response, and the optical properties of the atmosphere permit remote sensing of the surface temperature $[4,5]$. Furthermore, since the water is the only object whose emissivity is constant over a large area and is around one (emissivity of the water $\approx$ 1 ) in the spectral channel of interest, the SST can be reliably estimated from its radiance $[3,6,7]$.

This study used data from sensors called MODIS (Moderateresolution Imaging Spectroradiometer) on the board the satellites Terra (launched on December 18, 1999) and Aqua (launched on May 4 , 2002) for predicting and mapping the SST in Weda Bay. MODIS sensors on Terra and Aqua satellites were chosen because these satellites provided a $2330 \mathrm{~km}$ viewing swath with medium spatial resolution (500-1000 m). They are high sensitivity (12 bits), acquiring data at 36 high spectral resolution bands (between 0.415 and 14.235 $\mu \mathrm{m})$, and provide almost daily coverage. Both satellites were special designed for the observation of global dynamics, including terrestrial observation (band 1-7), as well as oceanic observation or ocean color study (band 8-16), and atmospheric observation, including SST (band 17-36). MODIS imagery has been widely used for the monitoring of SST and the lake surface temperature (LST) in Indonesia and abroad [8-16]. This research monitored SST in Weda Bay to estimate upwelling there. 


\section{Materials and Methods}

\section{Study sites and the collection of sea truth data}

Weda Bay is one of the three main bays on Halmahera Island, North Maluku Province (Figure 1). In-situ SST data were collected from 2 series of permanent stations, namely OP series stations (5 stations, station OP1 to OP5) and UP series station (13 stations, station UP 1 to UP 13). SST were measured using a CTD at those stations (Figure 1) from February to August 2007, except in July when no measurements were taken due to the rough seas. SST measurements were conducted at morning, noon, afternoon between AM to AM.

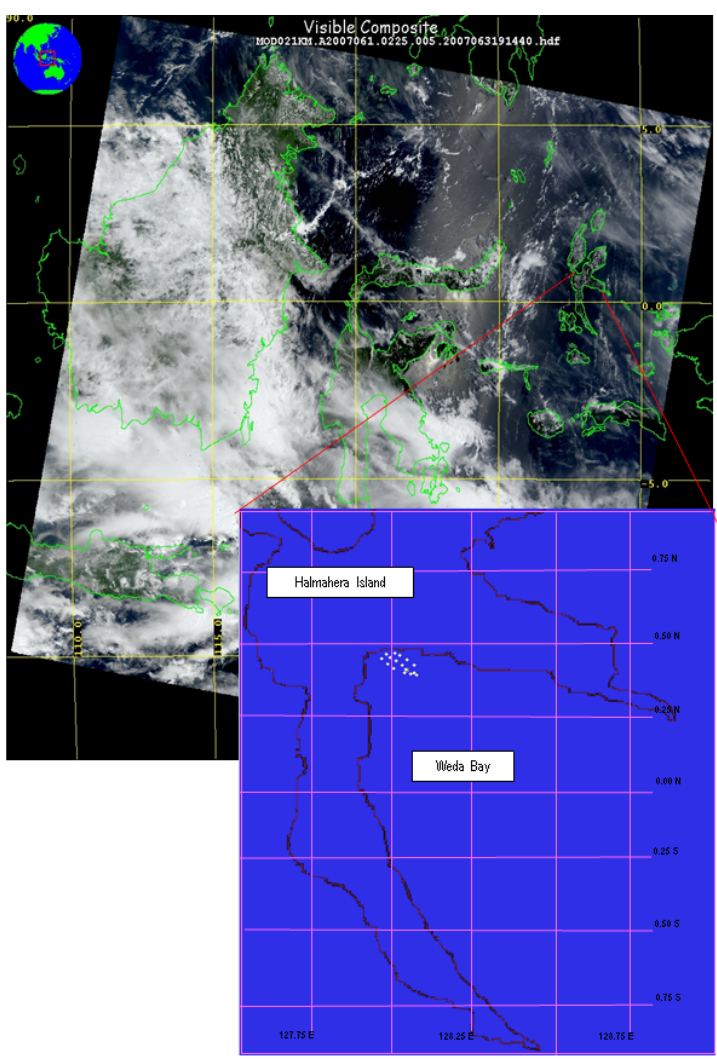

Figure 1: A MODIS images showing the map of study site (Weda Bay). White dots indicate the in situ measurements of water temperature from UP (13) and OP (5) stations that were used for developing the empirical algorithm to predict the SST of Weda Bay.

\section{Acquisition and processing of Terra and Aqua- MODIS satellite data}

The Terra and Aqua- MODIS Level-1 B (calibrated radiances) data were acquired from NASA Goddard Earth Sciences Distributed Active Archive Center (GES DAAC) http://ladsweb.nascom.nasa.gov/data/ search.html. These data contain calibrated earth view observations from MODIS bands 1-7 (for land application) that are aggregated to appear at $1 \mathrm{Km}$ from the original resolution of $250 \mathrm{~m}$ (band 1-2) and $500 \mathrm{~m}$ (band 3-7); band 8-16 (for ocean color study) and band 17-36 (for atmospheric study) at $1 \mathrm{Km}$ resolution [9]. Thus, for this study, the
MODIS data at $1 \mathrm{Km}$ resolution in the format MOD021KM (for Terra satellite images) and MYOD1KM (for Aqua satellite images) with a size of approximately 160 mega bytes $(\mathrm{Mb})$ were downloaded. The Terra satellite passes over Weda Bay at \pm 10:30 AM local time (1:30 GMT time) in descending node (from north to south), while Aqua at $\pm 1: 30$ PM (4:30 GMT) is in ascending node (from south to north).

From 36 available bands of MODIS, there are 5 bands of TIR, bands $20(3.7 \mu \mathrm{m}), 21(3.9 \mu \mathrm{m}), 23(4.0 \mu \mathrm{m}), 30(11 \mu \mathrm{m})$ and $31(12 \mu \mathrm{m})$. The first three bands were used to estimate the night-time SST, while the other two bands were used for daytime SST estimation. Therefore, in this study, we used only bands 30 and 31, because the available in-situ data were collected during daytime. MODIS data are in HDFEOS format, an evolving format developed by NASA for recording all information (data and meta-data) of a certain satellite data (Terra-, Aqua-MODIS, Aster, Landsat-7). Those data in HDF were converted to multi-band Geotiff format using a software program called HEG (HDFEOS to Geotiff). Converted data were ready to analyze using various images processing package software. In this study we used IDRISI ANDES (ver. 15) software for processing the Terra- and AquaMODIS images. Since this data covered an area of $2330 \mathrm{Km}$ viewing swath width $( \pm 2330 \times 2330$ pixels), then a window area covering all of Weda Bay and small parts of the surrounding areas $( \pm 165 \times 210$ pixels) were cropped from the entire images.

\section{SST empirical prediction model development and mapping}

There are two approaches to convert the relative spectral response (Digital Number values/DN) of single TIR band into the SST either theoretically or empirically. The theoretical approach utilizes the internal reference blackbody of the thermal sensing systems, and converts the TIR DN into SST by integrating Plank's equation in the spectral region of interest $(10-13 \mu \mathrm{m})$, as in the works of Schott et al. and Bartolucci et al. [2,17]. The empirical approach correlates TIR DN values with SST measurements using linear regression, see Lathrop et al., Khorram et al. and Kahtaro et al. [18-20]. In this study we used the second approach.

For developing SST prediction model, we used only the in-situ SST measurements made on a clear (relatively free cloud) day by Terra- or Aqua-MODIS satellites that coincidently passed over Weda Bay on the same day. The TIR DN of MODIS band 30 and 31 values at the same coordinates as the SST measurements were extracted. These TIR DN were then correlated to the SST measurements using multiple linear regression, as follows, to estimate the SST.

\section{$\mathrm{SST}=\mathrm{ao}+\mathrm{a} 1 \times$ TIR DN Band $30+\mathrm{a} 2 \times$ TIR DN Band $31 \ldots . .1)$}

ao, a1 and $\mathrm{a} 2$ are dimensionless coefficients.

The data used in the development of the SST prediction model were the data collected from February to August 2007 (see Table 1), while other data outside of those dates were used for validating the model. To establish the statistical significance of the regression models, the correlation coefficient $(r)$, standard error of the mean estimate $(\mathrm{SE}(\mathrm{Y})$ ) and $\mathrm{F}$ values were used. In an ideal case, $\mathrm{r}$ should approach $100 \%$, $\mathrm{SE}(\mathrm{Y})$ should be zero (0), and the F value should be at least 4-5 times greater then $\mathrm{F}$ criterion (set at 99 or $95 \%$ of confidence level) which is an indication of negligible bias [21-23]. If those criteria were achieved, then we used the model for mapping the multi- temporal of the SST for the entire Weda Bay. The products of the map consist of single daily SST, 10-day average SST and average monthly SST maps. 
Citation: Tarigan S, Wouthuyzen S (2017) Mapping and Monitoring the Sea Surface Temperature in Weda Bay Using Terra and Aqua- Modis Satellites. J Remote Sensing \& GIS 6: 217. doi:10.4172/2469-4134.1000217

Page 3 of 6

\begin{tabular}{|c|c|c|c|c|c|c|}
\hline \multirow[b]{2}{*}{ Date } & \multirow{2}{*}{$\begin{array}{l}\text { Julian } \\
\text { date }\end{array}$} & \multirow[b]{2}{*}{ Satellites } & \multirow{2}{*}{$\begin{array}{l}\text { Station } \\
\text { No. }\end{array}$} & \multirow{2}{*}{$\begin{array}{l}\text { In-situ } \\
\text { Temp. }\end{array}$} & \multicolumn{2}{|l|}{$\begin{array}{l}\text { Digital } \\
\text { Values }\end{array}$} \\
\hline & & & & & Band-30 & Band-31 \\
\hline 2-Feb-07 & 33 & Aqua & OP-4 & 27.59 & 11450 & 12084 \\
\hline 2-Feb-07 & 33 & Aqua & OP-5 & 27.75 & 11224 & 11716 \\
\hline 3-Mar-07 & 63 & Aqua & OP-1 & 28.15 & 15636 & 16237 \\
\hline 3-Mar-07 & 63 & Aqua & OP-3 & 27.65 & 15650 & 16259 \\
\hline 9-Mar-07 & 68 & Terra & OP-1 & 29.28 & 10802 & 11305 \\
\hline 9-Mar-07 & 68 & Terra & OP-2 & 29.00 & 10847 & 11360 \\
\hline 9-Mar-07 & 68 & Terra & OP-3 & 28.99 & 10802 & 11360 \\
\hline 9-Mar-07 & 68 & Terra & OP-4 & 29.09 & 10836 & 11441 \\
\hline 9-Mar-07 & 68 & Terra & OP-5 & 29.43 & 10802 & 11326 \\
\hline 16-Mar-07 & 75 & Terra & OP-1 & 27.95 & 11020 & 11598 \\
\hline 16-Mar-07 & 75 & Terra & OP-2 & 28.99 & 11020 & 11598 \\
\hline 16-Mar-07 & 75 & Terra & OP-3 & 28.89 & 11103 & 11655 \\
\hline 23-Mar-07 & 83 & Aqua & OP-1 & 28.51 & 13476 & 13934 \\
\hline 23-Mar-07 & 83 & Aqua & OP-2 & 29.01 & 13134 & 13533 \\
\hline 23-Mar-07 & 83 & Aqua & OP-3 & 28.92 & 13042 & 13389 \\
\hline 23-Mar-07 & 83 & Aqua & OP-4 & 29.37 & 12487 & 12752 \\
\hline 23-Mar-07 & 83 & Aqua & OP-5 & 29.55 & 13184 & 13533 \\
\hline 11-Apr-07 & 101 & Aqua & OP-2 & 30.53 & 15554 & 16198 \\
\hline 11-Apr-07 & 101 & Aqua & OP-3 & 30.30 & 15543 & 16187 \\
\hline 11-Apr-07 & 101 & Aqua & OP-4 & 30.26 & 15535 & 16179 \\
\hline 11-Apr-07 & 101 & Terra & OP-2 & 30.53 & 12158 & 12814 \\
\hline 11-Apr-07 & 101 & Terra & OP-3 & 30.30 & 12167 & 12814 \\
\hline 11-Apr-07 & 101 & Terra & OP-4 & 30.26 & 12155 & 12840 \\
\hline 4-May-07 & 124 & Terra & OP-1 & 29.47 & 10103 & 10569 \\
\hline 4-May-07 & 124 & Terra & OP-2 & 29.63 & 10029 & 10479 \\
\hline 4-May-07 & 124 & Terra & OP-3 & 29.69 & 10029 & 10479 \\
\hline 18-Мау-07 & 138 & Aqua & OP-1 & 29.06 & 15362 & 15937 \\
\hline 18-Мау-07 & 138 & Aqua & OP-2 & 30.07 & 15341 & 15901 \\
\hline 18-Мау-07 & 138 & Aqua & OP-3 & 30.02 & 15449 & 16014 \\
\hline 18-Мау-07 & 138 & Aqua & OP-4 & 29.86 & 15456 & 16040 \\
\hline 18-Мау-07 & 138 & Aqua & OP-5 & 29.94 & 15239 & 15821 \\
\hline 18-Мау-07 & 138 & Terra & OP-1 & 29.06 & 11989 & 12589 \\
\hline 18-May-07 & 138 & Terra & OP-2 & 30.07 & 12009 & 12597 \\
\hline 18-May-07 & 138 & Terra & OP-3 & 30.02 & 11987 & 12596 \\
\hline 18-Мау-07 & 138 & Terra & OP-4 & 29.86 & 11887 & 12480 \\
\hline
\end{tabular}

\begin{tabular}{|c|c|c|c|c|c|c|}
\hline 18-Мay-07 & 138 & Terra & OP-5 & 29.94 & 11850 & 12463 \\
\hline 25-May-07 & 145 & Aqua & OP-1 & 29.79 & 11220 & 11920 \\
\hline 25-Мау-07 & 145 & Aqua & OP-2 & 29.16 & 10259 & 11070 \\
\hline 25-Мау-07 & 145 & Aqua & OP-3 & 29.29 & 8936 & 9787 \\
\hline 25-May-07 & 145 & Aqua & OP-4 & 29.40 & 6834 & 7660 \\
\hline 1-Jun-07 & 152 & Aqua & OP-1 & 29.12 & 15567 & 16191 \\
\hline 25-Мау-07 & 145 & Aqua & OP-5 & 29.47 & 6143 & 6955 \\
\hline 1-Jun-07 & 152 & Aqua & OP-2 & 29.57 & 15569 & 16171 \\
\hline 1-Jun-07 & 152 & Aqua & OP-3 & 29.76 & 15643 & 16247 \\
\hline 1-Jun-07 & 152 & Terra & OP-1 & 29.12 & 11877 & 12466 \\
\hline 1-Jun-07 & 152 & Terra & OP-2 & 29.57 & 11837 & 12418 \\
\hline 1-Jun-07 & 152 & Terra & OP-3 & 29.76 & 11784 & 12341 \\
\hline 15-Jun-07 & 166 & Terra & OP-1 & 29.52 & 11592 & 12166 \\
\hline 15-Jun-07 & 166 & Terra & OP-2 & 29.19 & 11540 & 12147 \\
\hline 15-Jun-07 & 166 & Terra & OP-3 & 29.05 & 11540 & 12128 \\
\hline 15-Jun-07 & 166 & Terra & OP-4 & 29.00 & 11582 & 12128 \\
\hline 15-Jun-07 & 166 & Terra & OP-5 & 29.14 & 11550 & 12128 \\
\hline 15-Jun-07 & 166 & Aqua & OP-1 & 29.52 & 13986 & 14607 \\
\hline 15-Jun-07 & 166 & Aqua & OP-2 & 29.19 & 13721 & 14363 \\
\hline 15-Jun-07 & 166 & Aqua & OP-3 & 29.05 & 12542 & 13385 \\
\hline 15-Jun-07 & 166 & Aqua & OP-4 & 29.00 & 11754 & 12665 \\
\hline 15-Jun-07 & 166 & Aqua & OP-5 & 29.14 & 12104 & 12966 \\
\hline 16-Aug-07 & 228 & Terra & UP-2 & 28.36 & 9561 & 9731 \\
\hline 16-Aug-07 & 228 & Terra & UP-3 & 28.16 & 9406 & 9999 \\
\hline 16-Aug-07 & 228 & Terra & UP-4 & 28.34 & 9435 & 9835 \\
\hline 16-Aug-07 & 228 & Terra & UP-5 & 28.46 & 9561 & 9595 \\
\hline 16-Aug-07 & 228 & Terra & UP-6 & 28.93 & 9308 & 9664 \\
\hline 16-Aug-07 & 228 & Terra & UP-7 & 28.77 & 9280 & 9736 \\
\hline 16-Aug-07 & 228 & Terra & UP-8 & 29.00 & 9327 & 9692 \\
\hline 16-Aug-07 & 228 & Terra & UP-9 & 28.84 & 9367 & 9776 \\
\hline 16-Aug-07 & 228 & Terra & UP-10 & 29.19 & 9230 & 9653 \\
\hline 16-Aug-07 & 228 & Terra & UP-11 & 29.00 & 9310 & 9741 \\
\hline 16-Aug-07 & 228 & Terra & UP-12 & 28.39 & 9381 & 9751 \\
\hline 16-Aug-07 & 228 & Terra & UP-13 & 28.62 & 9381 & 9811 \\
\hline
\end{tabular}

Table 1: In-situ measurements of SST conducted from February to August 2007. 


\section{Results and Discussion}

\section{Model development and SST mapping}

A total of 51 data sets of in-situ SST measurements from February to August 2007 were collected on dates the Terra- and Aqua- MODIS satellites both passed over Weda Bay. Since in one day it was possible to get images from Terra-satellites in the morning and Aqua-satellites in the afternoon, the available data sets actually numbered more than 51 (Table 1). All those data sets were used for developing the empirical algorithm/ model to predict the SST using the Digital Number (DN) values of TIR Band 30 and 31 of MODIS. Based on the data set in Table 1, the empirical prediction model for SSTs in Weda Bay can be expressed as follows:

\section{$\mathrm{SST}=27.15-0.001275 \times \mathrm{B} 30+0.001397 \times \mathrm{B} 31, \ldots 2)$}

where $\mathrm{B} 30$ and $\mathrm{B} 31$ are the $\mathrm{DN}$ values of Band 30 and Band 31 of Terra- or Aqua- MODIS satellites, respectively.

This model was developed using only 50 data sets out of the total available data sets (69). Because the accuracy or the quality of the insitu SST measurements was unknown, 19 datasets were excluded due to suspected bias, especially for low in-situ SST measurements $\left(27.59 \sim 28.16^{\circ} \mathrm{C}\right)$ in February and parts of March. This model introduced a high bias that tended to underestimate -1.45 to $-2.26^{\circ} \mathrm{C}$ for low in-situ SSTs in February and March. However, statistically, the above model is good enough to estimate the SSTs in Weda Bay after excluding those biased SST data. This was indicated by high correlation coefficient ( $\mathrm{r}=0.81$ ), low Root Mean Square (RMS) error $\left(0.29^{\circ} \mathrm{C}\right.$ ), and the ratio between $\mathrm{F}$ value and $\mathrm{F}$ criterion (set at $95 \%$ of confidence level) was 38.94: 3.17 or $\mathrm{F}$ value $>10$ times greater than $\mathrm{F}$ criterion, which an indication of negligible bias [21]. Figure 2 displayed the plot between in-situ SST measurements versus predicted SST, while Figure 3, showed its residual plot or plot of the bias (discrepancy between in-situ SST and predicted SST). At the bias range equal to $\pm 0.5^{\circ} \mathrm{C}$, all data sets $(100 \%)$ lay inside this range, but for more accurate prediction of $\pm 0.25^{\circ} \mathrm{C}$, there were only 24 points (48\%).

\begin{tabular}{|l|l|l|l|l|}
\hline Month & Terra & Aqua & Total & Remarks \\
\hline January 2007 & 5 & 6 & 11 & Used for mapping \\
\hline February & 5 & 3 & 8 & Used for Mapping \\
\hline March & 11 & 7 & 18 & Used for model and mapping \\
\hline April & 10 & 4 & 14 & Used for model and mapping \\
\hline May & 9 & 2 & 11 & Used for model and mapping \\
\hline June & 7 & 2 & 9 & Used for mapping \\
\hline July & 3 & 3 & 6 & Used mapping \\
\hline August & 5 & 4 & 9 & Used for model and mapping \\
\hline September & 5 & 5 & 10 & Used for mapping \\
\hline October & 6 & 2 & 8 & Used for mapping \\
\hline November & 3 & 1 & 4 & Used for mapping \\
\hline Total & 69 & 39 & 108 & \\
\hline
\end{tabular}

Table 2: Terra- and Aqua- MODIS satellites images used for developing the empirical model and SST maps of Weda Bay.
However, the range of $0.5^{\circ} \mathrm{C}$ is good enough for predicting the SST, and therefore, the model was applicable for mapping the SSTs in Weda Bay. A total of 108 images consisting of 69 images of Terra- and 39 images of Aqua- MODIS (Table 2) was used for making the SST maps. This table showed that the MODIS data are more available during March to May, but less in July and November.

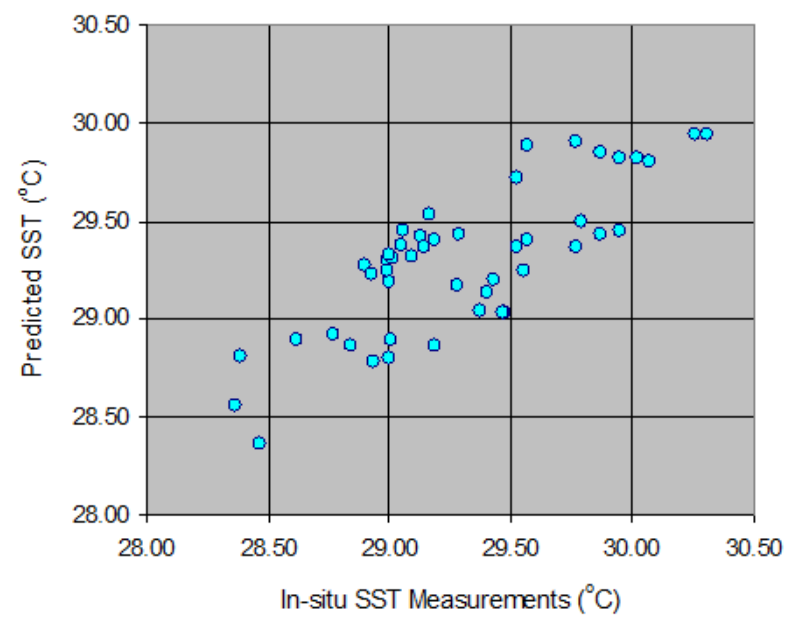

Figure 2: Plot of in-situ measurement SST and predicted SST derive using TIR bands of Terra- and Aqua MODIS satellites, by applying equation 2 .

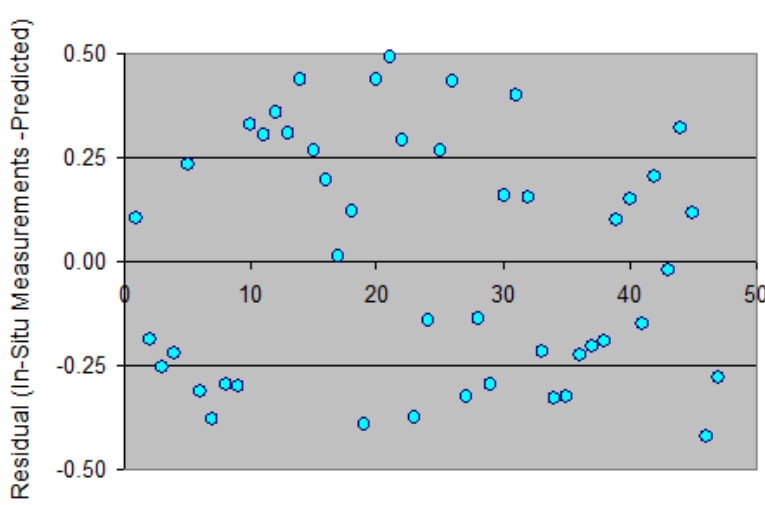

Figure 3: Residual plot showing that $100 \%$ of predicted SST lies within the bias of $\pm 0.5^{\circ} \mathrm{C}$, indicating the model was good enough for mapping the SST of Weda Bay.

\section{SST maps of Weda Bay}

The SST maps of Weda Bay consisted of daily, 10-day average and monthly maps of each month from January to November (Figures 1 to 22 in Appendix 1). The daily SST images in Appendix 1 showed that the SST ranges in the Weda Bay were narrow, between 28 to $30^{\circ} \mathrm{C}$, and flat without any distinct fluctuation of SSTs throughout the year. There 
are several dates when both Terra- and Aqua images were acquired in the same day. In almost cases, the Aqua image showed SST values higher by 0.4 to $0.6^{\circ} \mathrm{C}$ than the Terra images. This is due to the Aqua images being acquired in the afternoon (PM 13:30 local time), which is the warmer than the SST measured in morning when the Terra satellite passed over the Weda Bay (AM 10:30 local time).

Calculation of the average values of SST in Weda Bay was done only for 10-day average and monthly SST maps. Calculations were not carried out for the entire bay, but only for a window of $290 \times 200$ pixels or approximately $72 \times 50 \mathrm{~km}$ square as shown in Figure 4 . The SST values from that cropped window were then extracted and averaged.

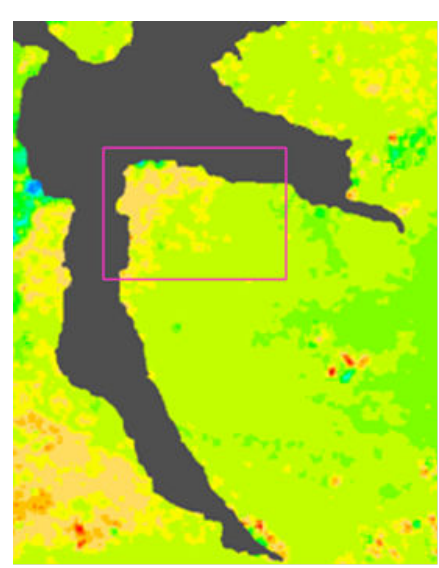

Figure 4: A window area of approximately $72 \times 50 \mathrm{~km}^{2}$ in which the 10 -day averages and monthly SSTs were calculated.

Figures 5 and 6 displayed the plots of the 10-day average and monthly SST, respectively. The 10-day average SST plot shows that the highest SST was found in the first 10 days of February $\left(30.28^{\circ} \mathrm{C}\right)$ followed by the second 10 days of April $\left(29.95^{\circ} \mathrm{C}\right)$ and the first 10 days of August $\left(29.89^{\circ} \mathrm{C}\right)$. The lowest SST was found during the first 10 days of March $\left(28.85^{\circ} \mathrm{C}\right)$ followed by the first 10 days of May $\left(29.03^{\circ} \mathrm{C}\right)$. From the second 10 days of May to the first 10 days of July, the SSTs were flat around $29.5^{\circ} \mathrm{C}$, and fluctuated slightly after that.

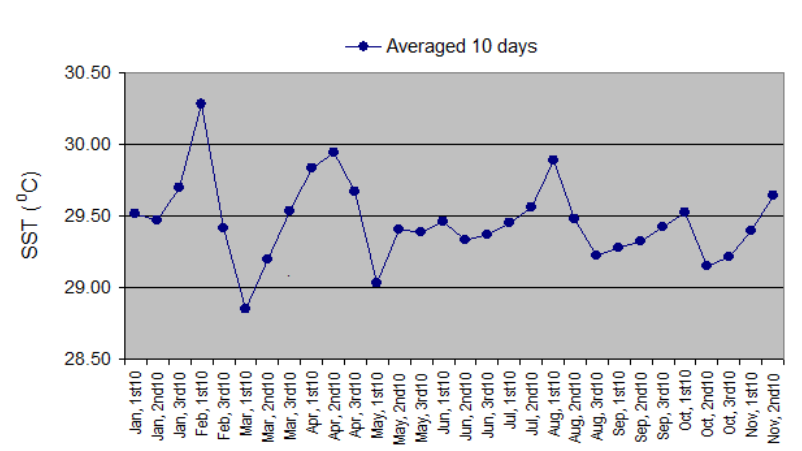

Figure 5: The averaged 10 days SST in the block windows areas as displayed in Figure 4.

The monthly SST plots in Figure 6 shows that they distribute in narrower ranges than the daily SST and 10 days averaged SST. The fluctuation of monthly SSTs is only $0.5^{\circ} \mathrm{C}$ between 29.25 and $29.75^{\circ} \mathrm{C}$ over the whole year. In comparison with the 10-day average SST plot in Figure 5, the SST distributions are more dynamic with its range of $1.5^{\circ} \mathrm{C}$, between 28.75 and $30.25^{\circ} \mathrm{C}$. Therefore, in future studies it is necessary to make 10-day average SST maps rather than monthly maps, because 10-day average SST maps are more useful for monitoring purposes.

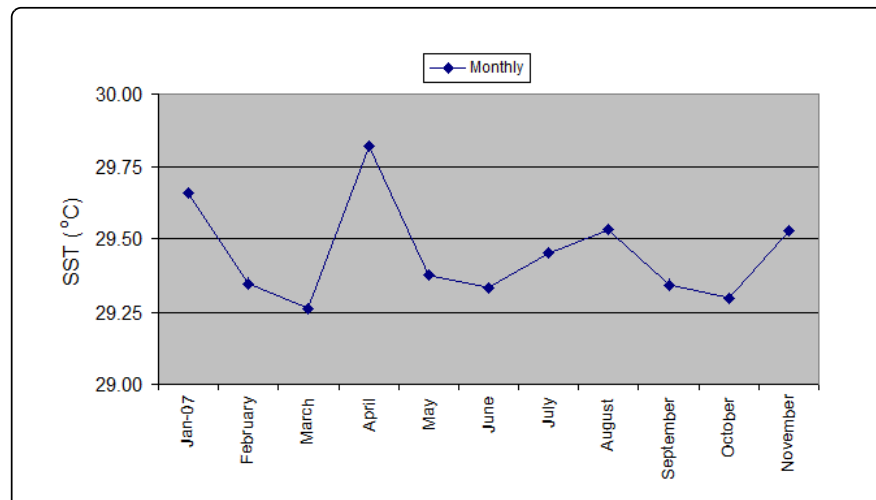

Figure 6: The average monthly SST in the block windows areas as displayed in Figure 4.

\section{SST map applications}

As already mentioned, temperature is one of the principal controls on all physical, chemical and biological processes in the environment. Thus, one of the important SST map applications is to know about and monitor upwelling in a water body such as Weda Bay. Upwelling is a very well-known physical process in the sea. During upwelling, water from the deeper layer with low temperature, high salinity, high level of nutrients (phosphorus and nitrogen) and low dissolved oxygen goes to the surface of the sea. This phenomenon is important to fisheries, because after the upwelling event, the productivity of the sea increases and this generates higher numbers of fish. In the upwelling areas, a low SST is always found compared to the higher SST of the surrounding waters. The SST differences could reach 2 to $4^{\circ} \mathrm{C}$, depend on the strength of the upwelling. There are many upwelling places in the Indonesian seas such as near Banda and Flores, in the Maluku Seas and Makassar Straits, south of Java and Bali and west of Sumatra (Indian Ocean).

Judging from the SST maps only (Figures in Appendix 1,8,9), the finding in this study indicated that no upwelling phenomena occurred in Weda Bay during 2007. However, upwelling in this bay could happen in the future or may have happened in the past. Since Terraimages have been available from 2000 till now, and Aqua- MODIS from 2002 to the present, we need to conduct long-term monitoring of the SST of Weda Bay. Furthermore, SST is not the only parameter that could detect the upwelling from the space. Another parameter such as chlorophyll-a concentration, which indicates phytoplankton abundance and is known as the ocean color parameter, is another parameter that could easily be monitored too. Therefore, SST and chlorophyll-a concentration are the best parameters for effective and efficient monitoring of the upwelling phenomena in the Weda Bay from the space. This must be done in the near future in order to get a clear understanding of the characteristics of this bay. 


\section{Concluding Remarks}

- Monitoring and mapping the daily, 10-day average, and monthly SST of Weda Bay for 2007 using Terra- and Aqua- MODIS satellites images have been conducted with good results. Those satellites proved their ability and usefulness as monitoring tools. Reinart et al. found the same result in monitoring lake temperatures in Sweden, where temperature varies greatly with space and time.

- The SST distribution in the Weda Bay from the daily and 10-day average SST maps showed a flat and narrow ranging of SST of $2^{\circ} \mathrm{C}$, between 28 and $30^{\circ} \mathrm{C}$ all over the year. Monthly SST maps showed a narrower range of $0.5^{\circ} \mathrm{C}$, between 29.25 and $29.75^{\circ} \mathrm{C}$. This finding indicated no upwelling phenomena occurred in this bay during 2007.

- It is necessary to conduct long-term monitoring of Weda Bay from space, not only SST, but also for the ocean color parameter (chlorophyll-a concentration), in order to get a clear understanding of the characteristics of this bay that are useful for managing the environment.

\section{Acknowledgment}

Thanks to PT Weda Bay on the cost of the collection of field data in Weda Bay.

\section{References}

1. Lillesand TM, Kiefer RW (1987) Remote Sensing and Image Interpretation. John Willey \& Sons, New Jersey, USA, pp: 1-721.

2. Bartolucci LA, Chang M, Anuta PE, Graves MR (1988) Aton Landsat TM thermal Inrared data. IEEE Transaction on Geosciences and Remote Sensing 8: 1509-1522.

3. EOSAT b. Landsat Themathic Mapper Imagery. Earth Observing Satellite Company, pp: 1-40.

4. Maul GA (1985) Introduction to satellite Oceanography. Martinus Nijhoff Publisher, Netherlands pp: 1-606.

5. Minnet PJ (1986) On the use of synthetic $12 \mu \mathrm{m}$ data in split Window retrieval of sea surface temperature from AVHRR measurement. Int J Remote Sensing 7: 1887-1891.

6. Becker F (1987) The impact of spectral emissivity on the measurement of land surface temperature from satellite. Int J Remote Sensing 8: 1509-1522.

7. MacCallum SN, Merchant CJ (2012) Surface water temperature observations of large lakes by optimal estimation. Canadian Journal of Remote Sensing 3: 25-45.
8. Tim JS, Peter IM, Steve BG, Samantha JL (2001) Remote sensing of sea surface temperature and chlorophyll during Lagrangian experiments at the Iberian margin. Progress in Oceanography 51: 269-281.

9. Savtchenko A, Quzounov D, Ahmad S, Acker J, Leptoukh G, et al. (2004) Terra and Aqua MODIS products available from NASA GES DAAC. Advances in Space Research 34: 710-714.

10. Wan Z, Zhang Y, Zhang Q, Li Z (2004) Quality assessment and validation of the MODIS global land surface temperature. International Journal of Remote Sensing 25: 261-274.

11. Oesch DC, Jaquet JM, Hauser A, Wunderle S (2005) Lake surface water temperature retrieval using advanced very high-resolution radiometer and Moderate Resolution Imaging Spectroradiometer data: Validation and feasibility study. Journal of Geophysical Research 110: C12.

12. Chan PK, Gao BC (2005) A comparison of MODIS, NCEP, and TMI sea surface temperature datasets. IEEE Geosci Remote Sens Lett 2: 270-274.

13. Reinart A, Reinhold M (2008) Mapping surface temperature in large lakes with MODIS data. Remote Sensing of Environment 112: 603-611.

14. Chavula G, Brezonik P, Thenkabail P, Johnson T, Bauer M (2009) Estimating the surface temperature of Lake Malawi using AVHRR and MODIS satellite imagery. Physics and Chemistry of the Earth, Parts A/B/C 34: 749-754.

15. Nehorai R, Lensky IM, Lensky NG, Shiff S (2009) Remote sensing of the Dead Sea surface temperature. Journal of Geophysical Research 114: 4-11.

16. Narayanan M, Vasan DT, Bharadwaj AK, Thanabalan P, Dhileeban N (2013) Comparison and validation of sea surface temperature(SST) using MODIS and AVHHRR sensor data. International Journal of Remote Sensing and Geoscience 2: 2319-3484.

17. Schott JR, Volchok WJ (1985) Thematic mapper thermal infrared calibration. Photogram Engineering and Remote Sensing 51: 1351-1357.

18. Lathrop Jr RG, Lillesand TM (1987) Calibration of Thematic Mapper therma data for water surface temperature mapping: case study on the great lakes. Remote Sensing of Environment 22: 297-307.

19. Kohrram S, Cheshire H, Geraci AL, La Rosa G (1991) Water quality mapping of Agusta, Itally from Landsat-TM data. Int J Remote Sensing 12: 803-808.

20. Kohtaro H, Murakami H, Sakaida F, Kawamura H (2007) Algorithm and validation of sea surface temperature observation using MODIS sensors aboard Terra and Aqua in the western North Pacific. Journal of Oceanography 63: 267-280.

21. Drapper NR, Smith H (1981) Applied Regression Analysis. 2nd Edn, John Willey \& Sons, New Jersey, USA, pp: 1-709.

22. Lathrop Jr RG, Lillesand TM (1986) Use of thematic Mapper to access water quality in the Green Bay, Central Lake Michigan. Photogram Engineering and Remote Sensing 52: 671-680.

23. Witlock CH, Kuo CY, LeCroy SR (1982) Criteria for the use regression analysis for remote sensing sediments and pollutants. Remote Sensing of Environment 12: 151-165. 